\title{
Quantifying rainfall-runoff relationships on the Melkassa Hypo Calcic Regosol ecotope in Ethiopia
}

\author{
WA Welderufael ${ }^{1,2}$, PAL le Roux $^{1 *}$ and M Hensley ${ }^{1}$ \\ ${ }^{1}$ Department of Soil, Crops and Climate Sciences University of the Free State, Bloemfontein 9300, South Africa \\ ${ }^{2}$ Department of Civil Engineering \& Built Environment, Central University of Technology, Bloemfontein, 9300, South Africa
}

\begin{abstract}
Droughts, resulting in low crop yields, are common in the semi-arid areas of Ethiopia and adversely influence the wellbeing of many people. The introduction of any strategy that could increase yields would therefore be advantageous. The objective of this study was to attempt to assess the influence of in-field rainwater harvesting (IRWH), compared to conventional tillage, on increasing the amount of water available to a crop like maize on a semi-arid ecotope at Melkassa situated in the eastern part of the Rift Valley.

To achieve the objective of the study rainfall-runoff measurements were made during 2003 and 2004 on $2 \mathrm{~m}$ x $2 \mathrm{~m}$ plots provided with a runoff measuring system and replicated 3 times for each treatment. There were 2 treatments: conventional tillage (CT) on which hand cultivation was practised in a way that simulated the normal local CT; and a flat surface simulating the no-till, undisturbed surface of the IRWH technique (NT).

Rainfall-runoff measurements were made over 2 rainy seasons during which there were 25 storms with $>9 \mathrm{~mm}$ of rain. From the 25 storms, only the $2^{\text {nd }}$ season storms $(8$ storms) had runoff measurements. These storms were used for calibration and validation of the Morin and Cluff (1980) runoff model (MC Model). Appropriate values for final infiltration rate $\left(I_{f}\right)$, surface storage $(s)$ and for the crusting parameter $(\gamma)$ were found to be: $6 \mathrm{~mm} \cdot \mathrm{h}^{-1} ; 1.0 \mathrm{~mm}$ for NT and $6.0 \mathrm{~mm}$ for CT; $0.6 \mathrm{~mm}^{-1}$, respectively.

The measured runoff $(R)$ for the 2004 rainy season expressed as a fraction of the rainfall during the measuring period $(P)$, i.e. $R / P$, gave values of 0.59 and 0.40 for the NT and CT treatments, respectively. There was a statistical difference between the runoff on the 2 treatments.

Selected results from 7 years of field experiments with IRWH at Glen in South Africa were used together with measured maize yields and climate data over 16 seasons on the nearby Melkassa Experiment Station to estimate the yield benefits of IRWH compared to CT on the ecotope studied. The results ranged between 35 and $1437 \mathrm{~kg}$ with a mean of $711 \mathrm{~kg} \cdot \mathrm{ha}^{-1}$ over the 16 years. At Melkassa this was an estimated yield increase ranging from $13 \%$ to $49 \%$. The mean increase was $33 \%$.
\end{abstract}

Keywords: in-field rain-water harvesting, maize, yield increase, rainfall intensity, runoff, semi-arid ecotope

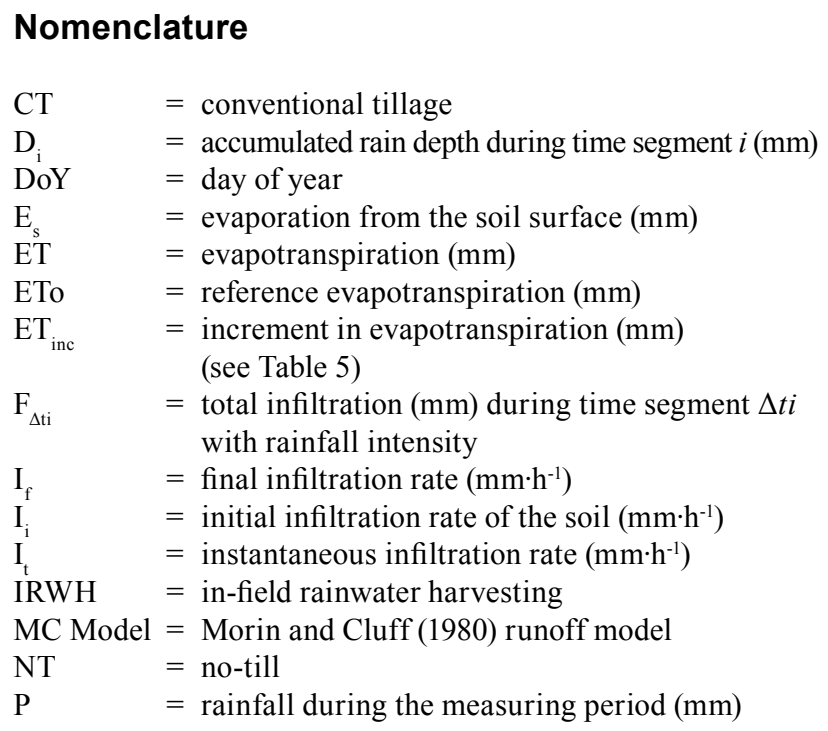

* To whom all correspondence should be addressed.

+2751 401 2386; fax: +2751 4012212 ;

e-mail: LeRouxPA.SCI@ufs.ac.za

Received 11 February 2008; accepted in revised form 11 September 2009.
$\mathrm{Pi} \quad=$ rainfall intensity $\left(\mathrm{mm} \cdot \mathrm{h}^{-1}\right)$

$\mathrm{Pi}=$ rainfall intensity during time segment $i\left(\mathrm{~mm} \cdot \mathrm{h}^{-1}\right)$

$\mathrm{s} \quad=$ surface storage

$\mathrm{V}=$ crusting parameter $\left(\mathrm{mm}^{-1}\right)$

$\mathrm{R}=\operatorname{runoff}(\mathrm{mm})$

$\mathrm{R}_{R^{\mathrm{i}}} \quad=$ runoff during time segment $i$ of the storm (mm)

$\frac{R}{p} \quad=$ ratio of runoff to rainfall (dimensionless)

RWP $\quad=$ rain-water productivity $\left(\mathrm{kg} \cdot \mathrm{mm}^{-1}\right)$

$\mathrm{SD}_{\mathrm{i}} \quad=$ maximum storage and detention $(\mathrm{mm})$

$\mathrm{SD}_{\mathrm{m}} \quad=$ maximum surface detention $(\mathrm{mm})$

$\mathrm{T}=$ transpiration $(\mathrm{mm})$

$\mathrm{t} . \quad=$ time from beginning of the storm $(\mathrm{h})$

$\mathrm{WP}_{\mathrm{ET}} \quad=$ water productivity for a particular growing season expressed in terms of the grain yield per unit of water used for evapotranspiration $\left(\mathrm{kg} \cdot \mathrm{ha}^{-1} \cdot \mathrm{mm}^{-1}\right)$

\section{Willmot statistical parameters}

$\begin{array}{ll}\mathrm{D} \text {-index }= & \text { index of determination } \\ \mathrm{MAE}= & \text { mean absolute error } \\ \mathrm{RMSE}= & \text { root main square error; with subscripts } s \text { and } \\ & u \text { indicating the contributions of systematic and } \\ & \text { unsystematic error, respectively } \\ = & \text { regression coefficient }\end{array}$




\section{Introduction}

More than $80 \%$ of Ethiopia's population is involved in agriculture, the backbone of the country's economy. Crop production is mostly under rain-fed conditions, most of which is marginalised by water stress (Ministry of Agriculture (MoA), 2000). This, and the frequent droughts, is a serious threat to those engaged in agriculture. The optimum utilisation of rain-water is therefore of utmost importance, requiring diligent adherence to the principle of 'more crop per drop', as appropriately stated recently by the former UN Secretary General, Kofi Annan. In scientific terms this means improving RWP, recently defined by Botha (2007) as the total long-term grain yield divided by total long-term rainfall.

One way of improving RWP is through the use of water harvesting. Many types of water conservation techniques that show significant crop yield increases have been tested worldwide (Berry and Mallet, 1988; Mwakalila and Hatibu, 1993; Kronen, 1994; Gicheru et al., 1998 and Ojasvi et al., 1999). A technique that has given good results in a semi-arid area of South Africa is IRWH as described by Hensley et al. (2000). This technique is also known as mini-catchment runoff farming (Oweis et al., 1999). The technique is illustrated in Fig. 1. It combines the advantages of water harvesting from the notill, flat, crusted runoff strip, and decreased evaporation from the deeply infiltrating runoff water which accumulates in the mulched basin area. The technique led to maize yield increases of between $25 \%$ and $50 \%$ compared to conventional tillage practices, and resulted in significant increases in RWP. It was shown that the technique is suited to semi-arid areas with crusting soils that have a high water storage capacity (Botha et al., 2003).

Rainfall in semi-arid areas with fine-textured soils is mainly lost through evaporation from the soil surface $(E s)$ and runoff $(R)$. Under these conditions $E s$ can be $60 \%$ to $70 \%$ of the annual rainfall (Bennie and Hensley, 2001), and $R$ can vary between $8 \%$ and $49 \%$ of the annual rainfall depending on the prevailing conditions (Haylett, 1960; Du Plessis and Mostert, 1965; Bennie et al., 1994; Hensley et al., (2000) and Botha et al., 2003). Studies by Morin and Benyamini (1977) and Morin and Cluff (1980) showed that the most important factors influencing runoff in semi-arid areas were: rainfall intensity $(P i)$; the final infiltration rate of the soil $\left(I_{p}\right)$, which is greatly

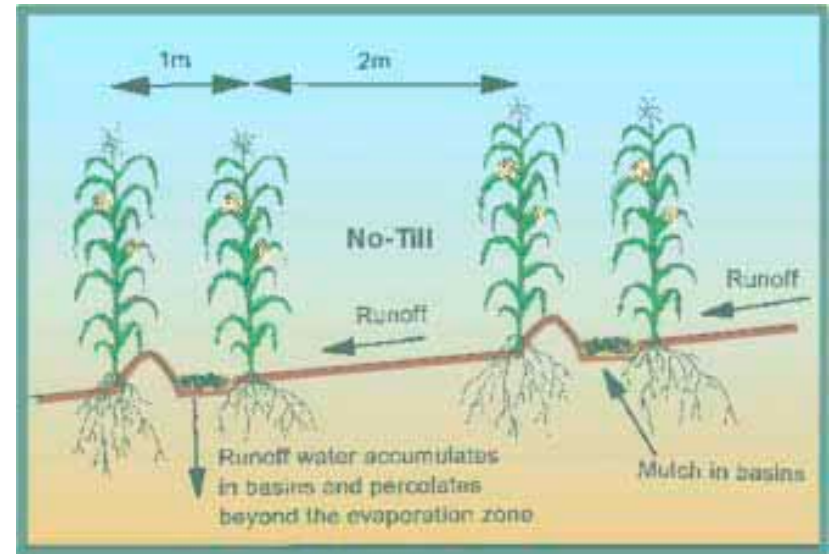

Figure 1

A diagrammatic description of the no-till, mulching, basin tillage, in-field rain-water harvesting (IRWH) production technique (Hensley et al., 2000) decreased by crusting; the extent to which the soil surface can store water before runoff starts which is described by a parameter termed surface detention $(S D)$; and a crusting parameter $(\gamma)$ describing its rate and extent of development. Their studies resulted in the formulation of a runoff model that satisfactorily predicted runoff from crusted soils in Arizona (Morin and Cluff, 1980), and in Israel (Morin et al., 1983). The model has been successfully used by Zere et al. (2005) for predicting the runoff measured by Du Plessis and Mostert (1965) over 18 years on a Tukulu form soil (Soil Classification Working Group, 1991) at Glen, South Africa.

The basis for the Morin and Cluff (1980) runoff model is provided by the following infiltration equation for crusted soils developed by Morin and Benyamini (1977):

$$
I_{t}=I_{f}+\left(I_{i}-I_{f}\right) e^{-\gamma p t} i
$$

Morin and Cluff (1980) showed that by integrating Eq. (1) with regard to time, and introducing changes in $P i$ over time segments of a storm $(\Delta t i)$, the following expression was valid:

$$
F_{\Delta t i}=I_{f} \Delta t i+\left(\left(I_{i}-I_{f}\right) /-\gamma P i\right)\left[\exp \left(-\gamma D_{i}\right)-\exp \left(-\gamma D_{i-1}\right)\right]
$$

where:

$\mathrm{F}_{\Delta \mathrm{ti}}=$ total infiltration during time segment $\Delta \mathrm{ti}$ with rainfall intensity Pi (mm)

The other parameters are as defined for Eq. (1).

If the soil surface were such that it did not store any water before runoff occurred, then for any time segment during which $P i>I_{p}$ the runoff for each time segment $\Delta t i$ of a storm, i.e. $R i$, could be calculated as:

$$
R i=P i \Delta t i-F_{\Delta t i}
$$

This is, however, not the case in practice as a soil surface always has some degree of surface roughness which will cause rain-water to accumulate, to an extent dependent on the degree and configuration of the roughness before runoff commences. Morin and Cluff (1980) deal with this factor by combining the $D i$ of Eq. (2) and 'a surface detention' parameter $(S D)$ into a parameter, $S D m$, termed 'maximum storage and detention'. By introducing this term into Eq. (3) they showed that it was possible to compute the runoff of any storm, segment by segment, using the following equation:

$$
R_{i}=P_{i} \Delta t i-F_{\Delta t i}+\left(S D_{i-1}-S D_{m}\right)
$$

Substitution of the right-hand side of Eq. (2) into the $F_{\Delta t i}$ term of Eq. (4) provides the complete Morin and Cluff (1980) runoff equation, i.e. Eq. (5):

$$
\begin{aligned}
R i= & P i \Delta t i-\left\{I A t i+\left(\left(I_{i}-I_{f}\right) / \gamma P i\right)\left[\exp (\gamma D i)-\exp \left(-\gamma D_{i-1}\right)\right]\right\} \\
& +\left(S D_{i-1}-S D_{m}\right)
\end{aligned}
$$

Equation (5) provides the basis for the MC Model. It enables the computation of the runoff of any storm, segment by segment.

Now consider the importance of the flat, crusted, no-till runoff strip in Fig. 1 in relation to Eq. (5). The parameters $S D m$ and $I_{f}$ are minimised, and $R i$ into the basin area is therefore maximised. The result is efficient conservation of runoff water which otherwise would have been lost. Values for $I_{i}$ and $I_{f}$ are relatively easily measured for a particular soil. Therefore if $P i$ and $R$ are measured on an experimental plot (rainfall-runoff 
relationships) $\gamma$ and SDm can be determined by iteration. The Morin and Cluff (1980) runoff model (MC Model) is thus clearly well suited for predicting the benefits of IRWH for crop production in semi-arid areas with crusted soils. It was therefore concluded that if rainfall-runoff relationships on selected ecotopes in Ethiopia could be determined, it would enable researchers to quantify the extent to which the IRWH technique would result in increased yields.

\section{Hypothesis}

- The in-field water harvesting technique described in Fig. 1 will result in increased crop yields compared with conventional tillage on certain semi-arid ecotopes of Ethiopia.

- The MC Model will satisfactorily predict runoff on the chosen ecotopes.

- It will be possible to make reasonable estimates of yield increases on the selected ecotopes using IRWH by predicting the extent of runoff collected in the basins, and therefore prevented from leaving the field and becoming unavailable to the crop.

\section{Objectives}

- To quantify rainfall-runoff relationships on the semi-arid Melkassa ecotope in Ethiopia over 2 rainy seasons.

- To calibrate the MC Model for the Melkassa ecotope.

- To estimate for the Melkassa ecotope the maize yield benefits using the IRWH technique described in Fig. 1, compared to conventional tillage. Data from the first objective will be used to do this.

\section{Procedure}

\section{Study site}

The study was carried out at Melkassa in one of the semi-arid regions of Ethiopia for 2 main rainy seasons during 2003 and 2004. Melkassa is located in the central part of the rift valley at longitude $39.31^{\circ} \mathrm{E}$ and latitude $8.43^{\circ} \mathrm{N}$. The altitude is $1550 \mathrm{~m}$ a. m. s. 1. and the chosen site represents a gently sloping plain with a slope ranging from $0 \%$ to $5 \%$ comprising a foot slope of the rift valley. The ecotope is described by the geographic site name followed by the name of the soil. The soil is classified as a Hypo Calcic Regosol (WRB classification). The ecotope name is therefore Melkassa Calcic Fluvic Regosol. This soil covers about $10 \%$ of Ethiopia and about $16 \%$ of the rift valley (FAO, 1984; FAO, 1998b; Itanna, 2005).

\section{Experimental design}

The experiment was carried out at Melkassa Agricultural Research Center (MARK) research field with a slope of $1 \%$. There were 2 treatments and 3 replications in a randomised complete block design. The plot size was $2 \mathrm{~m}$ x $2 \mathrm{~m}$. The treatments were:

- Conventional tillage (CT), i.e. the normal/traditional farmer's tillage practice

- No tillage on a flat surface (NT), i.e. simulating the runoff strip of IRWH.

Both treatments were uncropped and weeds were controlled by hand weeding. The lower side of each plot was equipped with a runoff collecting device. Each plot was surrounded by a galvanised iron sheet protruding $20 \mathrm{~cm}$ to 30 $\mathrm{cm}$ above the surface of the soil, and inserted about $20 \mathrm{~cm}$ deep into the soil. This 'wall' served to isolate each plot hydraulically. Runoff was collected in a gutter at the lower side of the plot. The gutter channelled the runoff water into a $200 \ell$ barrel buried at the side of each plot.

Runoff data were collected for each rainfall event. The MC Model describes a rainstorm as a group of rain segments for which the breaks in the rain are less than $24 \mathrm{~h}$. Huff (1967) defines a storm as a rain period separated from a preceding and succeeding rainfall event by $6 \mathrm{~h}$ or more. The latter definition was used. Runoff was simply measured by recording the height of the runoff inside the barrel.

Rainfall amount and intensity was measured by an automatic tipping bucket rain gauge (Hobo Event (C) Onset Computer Corp, Model No. 7, Version No. 4) installed at the experimental site to store detailed data for every storm. Each bucket tip measures $0.2 \mathrm{~mm}$ in a time interval determined by the intensity of the rainfall. The rain gauge is capable of measuring $0.2 \mathrm{~mm}$ in $0.01 \mathrm{~s}$. The rain gauge was equipped with a data-logger with memory capacity of 32768 bytes. The data were downloaded to a laptop computer, and then prepared to $1 \mathrm{~min}$ intensity. The record included the starting date and time, as well as the terminating date and time of each storm. The data collected were analysed to characterise each rainstorm at the Melkassa ecotope during the measuring period.

\section{Ecotope characterisation}

\section{Climate}

The Melkassa Hypo Calcic Regosol ecotope is located about 15 $\mathrm{km}$ south-east of Nazret City. The main rainy season is during the months June to September, during which $68 \%$ of the annual rainfall occurs (Table 1). The measured Class A pan evaporation data $(E o)$ and the potential evapotranspiration (ETo), calculated using the Penman-Monteith equation, correlate well with $R^{2}$ of 0.92 . The highest evaporative demand occurs during the months of March, April and May. During these months, the mean maximum temperature $(T x m)$ is around $30^{\circ} \mathrm{C}$ while the mean relative humidity $(\mathrm{RHm})$ drops to $51 \%$. During the main crop growing season of June to September conditions are more favourable with $\mathrm{Txm}$ and $\mathrm{RHm}$ approximately $27^{\circ} \mathrm{C}$ and $64 \%$ respectively.

\begin{tabular}{|c|c|c|c|c|c|c|c|c|}
\hline \multicolumn{8}{|c|}{ Table 1 } \\
\multicolumn{8}{|c|}{$\begin{array}{c}\text { Long-term (1977-2003) mean monthly climatic } \\
\text { data of Melkassa meteorological station. } \\
\text { ETo is Penman-Monteith reference ET }\end{array}$} \\
\hline Month & $\begin{array}{c}\text { Rainfall } \\
(\mathbf{m m})\end{array}$ & $\begin{array}{c}\text { MinT } \\
\left({ }^{\circ} \mathbf{C}\right)\end{array}$ & $\begin{array}{c}\text { MaxT } \\
\left({ }^{(} \mathbf{C}\right)\end{array}$ & $\begin{array}{c}\text { RH } \\
(\%)\end{array}$ & $\begin{array}{c}\text { Sshine } \\
\text { (h) }\end{array}$ & $\begin{array}{c}\text { Wind } \\
\text { sp } \\
\text { (K/h) }\end{array}$ & $\begin{array}{c}\text { ETo } \\
(\mathbf{m m})\end{array}$ & A.I \\
\hline J & 14 & 12 & 28 & 52 & 8.9 & 11 & 167 & 0.084 \\
\hline F & 26 & 13 & 29 & 50 & 8.7 & 12 & 167 & 0.156 \\
\hline M & 51 & 15 & 30 & 52 & 8.3 & 11 & 189 & 0.270 \\
\hline A & 52 & 15 & 30 & 51 & 8.3 & 10 & 180 & 0.289 \\
\hline M & 52 & 16 & 31 & 51 & 8.9 & 10 & 186 & 0.080 \\
\hline J & 68 & 16 & 30 & 53 & 8.4 & 12 & 177 & 0.384 \\
\hline J & 186 & 16 & 27 & 67 & 7.0 & 12 & 149 & 1.248 \\
\hline A & 181 & 15 & 26 & 69 & 7.2 & 10 & 140 & 1.293 \\
\hline S & 82 & 14 & 27 & 65 & 7.3 & 6 & 135 & 0.607 \\
\hline O & 42 & 12 & 29 & 50 & 8.6 & 8 & 164 & 0.256 \\
\hline N & 8 & 11 & 28 & 46 & 9.7 & 11 & 171 & 0.047 \\
\hline D & 11 & 11 & 28 & 49 & 9.5 & 11 & 171 & 0.064 \\
\hline Total & 772 & & & & & & 1994 & \\
\hline Mean & & 14 & 29 & 55 & 8.4 & 10 & & $\mathbf{0 . 3 8 7}$ \\
\hline
\end{tabular}




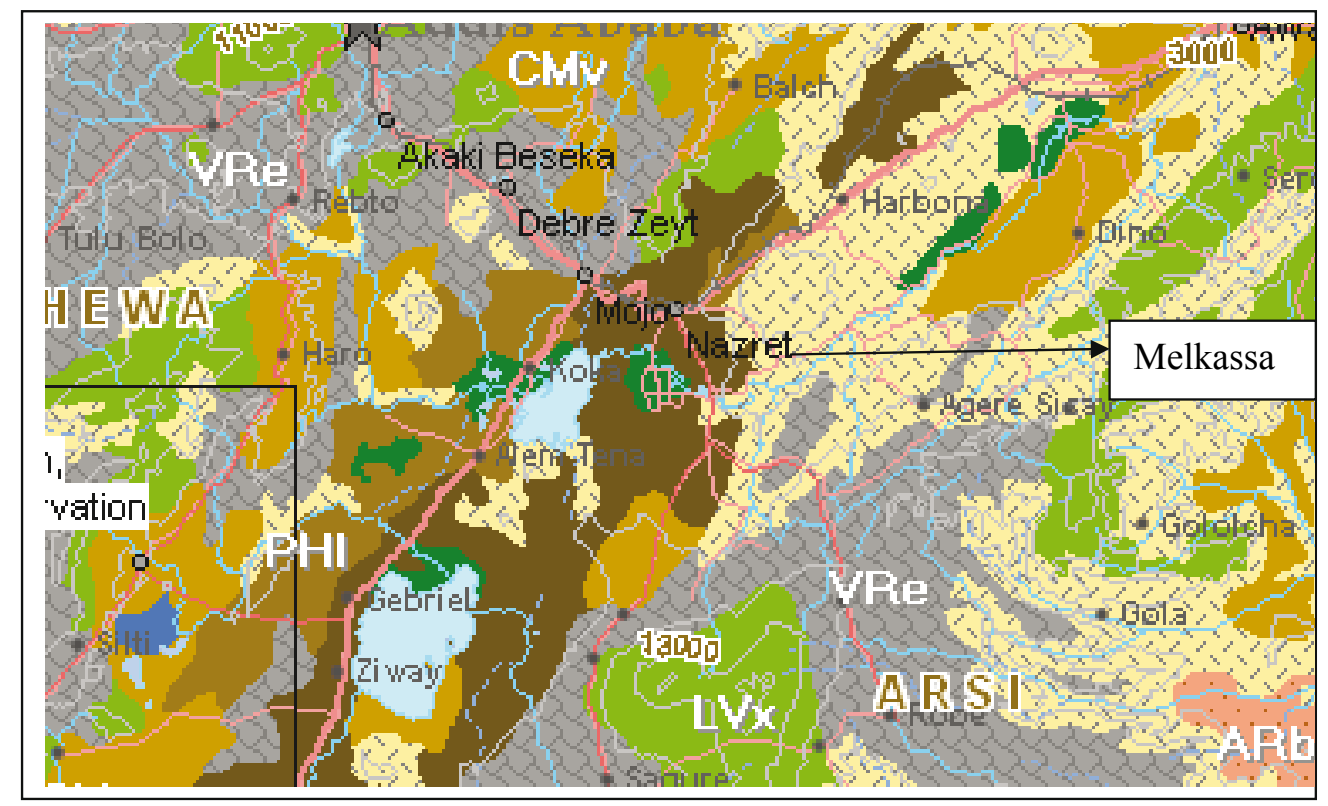

Figure 2

Soil map of the Rift Valley showing the experimental site (FAO, 1998a)

Soils of East Africa Source: FAO, 1998. Map: DEVECOL

Fluvisols

Arenosols

Leptosols, Regosols

Cambisols

Ferralsols

Acrisols, Lixisols, Alisols, Plinthosols

Solonchaks, Solonetz, Gypsisols, Calcisols

Luvisols, Nitisols, Planosols, Podzols

Vertisols

Chernozems, Phaeozems, Greyzems

Andosols

Gleysols

Histosols

Swamp

According to the recent agroecological zones classification of Ethiopia (MoA, 2000), the Melkassa Hypo Calcic Regosol ecotope falls in the zone termed hot to warm semi-arid lowlands (SA1). This belt exhibits 2 growing seasons of $50 \mathrm{~d}$ and $100 \mathrm{~d}$ in length for the $1^{\text {st }}$ and $2^{\text {nd }}$ seasons, respectively, and has an annual rainfall $(P)$ and potential evapotranspiration (PET) of about $772 \mathrm{~mm}$ and $1994 \mathrm{~mm}$, respectively. The aridity index $(A I)(P / P E T)$ of 0.39 (Table 1) identifies this as a semi-arid area.

\section{Soil}

A profile pit was dug to a depth of $3000 \mathrm{~mm}$. The soil profile was described and classified as follows: Hypo Calcic Regosol according to the World Resource Base System (FAO, 1998b); Etosha Vetkuil (2111) according to the South African System (Soil Classification Working Group, 1991); Regosol according to the FAO system (FAO, 1984). A soil map (FAO, 1998a) of the Rift Valley in this vicinity shows the dominance of the Regosols (Fig. 2). Important characteristics of the Melkassa soil are a favourable clay loam texture of the fine earth throughout the profile, with high silt content. The topsoil is strongly crusting. The water holding capacity of the potential root zone for maize is considered to be high.

Determinations of the following physical properties were made: drainage curve; soil water retention curves; bulk density; initial $\left(I_{i}\right)$ and final $\left(I_{f}\right)$ infiltration rates. Detailed results are presented in Welderufael (2006).

\section{Calibration and validation of the MC Model}

The measured rainfall and runoff data during the main season of 2004 were used to calibrate and validate the MC Model. Half of the data were used for calibration and the other half for validation. The data were used together with the determined values of $I_{i}$ and $I_{f}$ to run the model. The remaining parameters in the model, i.e. maximum surface detention $\left(S D_{m}\right)$, and $\gamma$ were fixed using a sensitivity analysis to obtain 'best fit' values. Model calibration was carried out by changing the values of $\gamma$ between 0.1 and 0.9 and $S D_{m}$ between 0 and $10 \mathrm{~mm}$, while keeping the measured and first approximation $I_{i}$ and $I_{f}$ values fixed. Once the optimum values for $\gamma$ and $S D_{m}$ were obtained, the sensitivity analysis was conducted manually and expertly (Madsen et al., 2002) to improve the $I_{f}$ value until the performance evaluation functions had reached their optimum level, and the observed and simulated runoff values matched reasonably well. Once the models were calibrated and the parameters fixed, validation was carried out on the remaining data using the procedure of Willmott (1981).

\section{Result and discussions}

\section{Rainfall-runoff relationships}

\section{Measurements}

Rainfall amounts $(P)$ and intensities $(P i)$ were measured during the main rainy seasons of 2003 and 2004. Runoff $(R)$ measurements were taken only for 2004. Melkassa storms generally exhibited intense rainfall during the $1^{\text {st }}$ and $2^{\text {nd }}$ quartiles of the events. Huff (1967) in his study at Illinois in the USA also found a similar pattern. In the 2003 rainy season the total amount of the rainfall for events $\geq 9 \mathrm{~mm}$ was $297 \mathrm{~mm}$. It was uniformly distributed throughout the season. There were six storms in July, seven in August and four in September, with $103 \mathrm{~mm}, 114 \mathrm{~mm}$ and $80 \mathrm{~mm}$ rainfall amounts, respectively (Table $2 \mathrm{~A}$ ). After calibration the MC Model predicted R/P as 0.3 and 0.16 on NT and CT plots respectively. Most of $R(57 \%)$ came from the 3 big storms on DoY 199, 236 and 249. For 2004, rainfall events $\geq 9 \mathrm{~mm}$ totalled $210 \mathrm{~mm}$. Rainfall for the entire season amounted to $251 \mathrm{~mm}$ producing $R / P$ values of 0.6 and 0.4 on the NT and CT plots respectively (Table 2 B). Unlike 
2003, the rainfall distribution in 2004 was non-uniform with 2 large storms in July followed by 1 large storm in August, and 1large storm each in September and October. This pattern would have caused a shortage of water during the flowering and maturity stage of the cropping period. During 2004, where measured runoff data were available, there was a significant difference at the 0.05 probability confidence level between the runoff on the 2 cultivation practices, with an overall mean per storm of $15.5 \mathrm{~mm}$ and $10.5 \mathrm{~mm}$ on the NT and CT plots respectively. The significant difference is attributed to the larger $S D_{m}$ values of the CT plots, presumably due to the 2 cultivation practices carried out on them during the season, and also due to the relatively few heavy storms capable of producing a similar crusted surface to that on the NT plots. The CT plot was cultivated at the beginning of the study and after the storm on DoY 212. This left a rough surface with considerable depressions that persisted for a longer period throughout the rainy season.

The MC Model was calibrated and validated using the rainfall-runoff measurements for 2004. The validated model was then used to predict $R$ for each storm of the 2003 season.

A similar procedure for model calibration and validation to that used at Dera was followed (Welderufael, 2006). Results are presented in Tables $3 \mathrm{~A}$ and B and Table 4. Appropriate values for $I_{f}$ and $\gamma$ were found to be $6 \mathrm{~mm} \cdot \mathrm{h}^{-1}$ and $0.6 \mathrm{~mm} \mathrm{~m}^{-1}$, respectively. These are the same as those selected for Dera (Welderufael, 2006).

The calibration procedure revealed that the $s$ values $\left(=S D_{m}\right)$ which gave the best results with the MC Model were $1 \mathrm{~mm}$ and $6 \mathrm{~mm}$ for the NT and CT plots, respectively. The following criteria were used for making the decision: $\mathrm{D}$-index, $\mathrm{R}^{2}$, and $\mathrm{RMSEu} / \mathrm{RSME}$ as close as possible to 1.0. A high value of the latter parameter is of particular importance since it indicates that the error is mainly not of a systematic nature.

These values, and their assessment parameters, are printed in bold (Table 3). Results of the validation test using these values, and the $I_{i}, I_{f}$ and $\gamma$ values (Table 3 ) are presented in Table 4. Significant aspects for both NT and CT are the relatively low RMSE values, very high $D$-index and $R^{2}$ values, and very high RMSEu/RMSE values. These are also compatible to the good overall correlation finally obtained between measured and predicted runoff values during 2004 for both the NT and CT treatments; $R^{2}$ values were 0.86 and 0.94 , respectively.

Once the model had been calibrated and validated, it was used to simulate the runoff of each storm during both years (Table 2). The good agreement between the measured and predicted values is reflected by the $R^{2}$ values of 0.86 and 0.94 for the NT and CT plots, respectively, for all the storms during the 2 seasons $(P \geq 9 \mathrm{~mm})$.

\section{Well-simulated storms}

Included are storms that start with intense rainfall $\left(P_{i}>I_{f}\right)$, and those storms that acquire high intensities $\left(P_{i}>I_{f}\right)$ later than in the $1^{\text {st }}$ quartile, and continued with $P_{i}>I_{f}$ for sufficient time to fulfil the sorptivity and $S D_{m}$ demand of the soil. A study of the rainfall vs. time graphs for a number of storms of this type indicates that about $4 \mathrm{~mm}$ of rain is needed to satisfy the requirements of sorptivity and $S D_{m}(1 \mathrm{~mm})$ on the NT plots. Therefore, subtracting $4 \mathrm{~mm}$ from the cumulative rainfall value at the point where $P_{i}$ becomes less than $I_{f}$, or at the point where the steepest part of the cumulative rainfall line terminates, will directly give an estimated amount of runoff on the NT plots.

Figures 3 and 4 show storms that begin with high intensity, during 2003 and 2004 respectively. For the storm on DoY 199 of year 2003, the point where $P_{i}<I_{f}$ is indicated by an arrowed line. The $P_{i}$ $>I_{f}$ part of the storm lasted for about $48 \mathrm{~min}$. The arrow gives a value of $18 \mathrm{~mm}$ on the $y$-axis of the cumulative rainfall. Therefore, subtracting $4 \mathrm{~mm}$ (the value of sorptivity $+S D_{m}$ ) from $18 \mathrm{~mm}$ will give $14 \mathrm{~mm}$. This is a similar result to the amount of runoff simulated by the Morin and Cluff (1980) runoff model for NT plot which equals $13.9 \mathrm{~mm}$ (Table 2). Similarly, for CT plots if we subtract 3 $\mathrm{mm}$ plus the value of $S D_{m}$ for CT plots $(3+6=9)$, we will obtain $9 \mathrm{~mm}$ of runoff. Again the result is very close to the one estimated by the model as 10.2 $\mathrm{mm}$ (Table 2). Since no measurements of runoff were recorded during 2003, this analysis enables us 


\begin{tabular}{|c|c|c|c|c|c|c|c|c|}
\hline \multicolumn{9}{|c|}{$\begin{array}{l}\text { TABLE } 3 \\
\text { Melkassa runoff calibration using the fixed parameters: } I_{i}=70 \mathrm{~mm} \cdot \mathrm{h}^{-1}, \\
I_{f}=6 \mathrm{~mm} \cdot \mathrm{h}^{-1} \text { and } \mathrm{Y}=0.6 \mathrm{~mm}^{-1} .\end{array}$} \\
\hline \multirow{10}{*}{$\begin{array}{l}\text { A. } \\
\text { NT } \\
\text { plots }\end{array}$} & \begin{tabular}{|l|} 
Objective \\
functions and \\
indices \\
\end{tabular} & $\mathrm{s}^{*}=5 \mathrm{~mm}$ & $\mathrm{~s}=4 \mathrm{~mm}$ & $\mathrm{~s}=3 \mathrm{~mm}$ & $\mathrm{~s}=2 \mathrm{~mm}$ & $\mathrm{~s}=1.5 \mathrm{~mm}$ & $\mathrm{~s}^{* *}=1 \mathrm{~mm}$ & $\mathrm{~s}=0.5 \mathrm{~mm}$ \\
\hline & RMSE & 3.60 & 3.12 & 2.72 & 2.51 & 2.45 & 2.41 & 3.07 \\
\hline & RMSEs & 3.22 & 2.76 & 2.32 & 2.03 & 1.90 & 1.78 & 1.31 \\
\hline & $\mathrm{RMSE}_{u}$ & 1.60 & 1.46 & 1.43 & 1.49 & 1.54 & 1.63 & 2.78 \\
\hline & MAE & 3.10 & 2.70 & 2.38 & 2.32 & 2.30 & 2.29 & 2.77 \\
\hline & $\mathrm{R}^{2}$ & 0.98 & 0.98 & 0.99 & 0.99 & 0.98 & 0.98 & 0.95 \\
\hline & D-index & 0.98 & 0.98 & 0.99 & 0.99 & 0.99 & 0.99 & 0.98 \\
\hline & Slope (b) & 0.93 & 0.95 & 0.98 & 1.01 & 1.01 & 1.02 & 1.04 \\
\hline & Intercept (a) & -2.37 & -2.26 & -2.14 & -2.12 & -2.03 & -1.93 & -1.63 \\
\hline & RMSEu/RMSE & 0.44 & 0.47 & 0.52 & 0.59 & 0.63 & 0.68 & 0.90 \\
\hline
\end{tabular}

$*_{s}=$ SDm of the MC model

** $=$ Selected $s$ value

\begin{tabular}{|c|c|c|c|c|c|}
\hline \multirow{10}{*}{$\begin{array}{c}\text { B. } \\
\text { CT } \\
\text { plots }\end{array}$} & $\begin{array}{l}\text { Objective } \\
\text { functions and } \\
\text { indices }\end{array}$ & $\mathrm{s}^{*}=8 \mathrm{~mm}$ & $\mathrm{~s}=7 \mathrm{~mm}$ & $\mathrm{~s}^{* *}=6 \mathrm{~mm}$ & $\mathrm{~s}=5 \mathrm{~mm}$ \\
\hline & RMSE & 1.79 & 1.77 & 1.88 & 1.92 \\
\hline & RMSEs & 1.14 & 0.87 & 0.82 & 0.97 \\
\hline & RMSEu & 1.39 & 1.54 & 1.69 & 1.65 \\
\hline & MAE & 1.24 & 1.24 & 1.32 & 1.48 \\
\hline & \begin{tabular}{|l|}
$\mathrm{R}^{2}$ \\
\end{tabular} & 0.98 & 0.98 & 0.98 & 0.98 \\
\hline & D-index & 0.99 & 0.99 & 0.99 & 0.99 \\
\hline & Slope (b) & 0.98 & 1.02 & 1.06 & 1.09 \\
\hline & Intercept (a) & -1.02 & -1.00 & -0.96 & -0.80 \\
\hline & RMSEu/RMSE & 0.77 & 0.87 & 0.90 & 0.86 \\
\hline
\end{tabular}

$*_{S}=$ SDm of the MC model

** $=$ Selected $s$ value

to further validate the MC Model.

The storm on DoY 252 of 2004 (Fig. 4) had $\mathrm{Pi}>I_{f}$ throughout its $22 \mathrm{~min}$ duration giving $22 \mathrm{~mm}$ of cumulative rainfall. Subtracting $4 \mathrm{~mm}$ from $22 \mathrm{~mm}$ gives an expected runoff of 18 $\mathrm{mm}$ on NT plots. The measured runoff was $16.4 \mathrm{~mm}$, while the model simulated $18.2 \mathrm{~mm}$. Using the same calculation as for storm on DoY 199 the expected runoff on CT plots is $13 \mathrm{~mm}$. The measured and simulated values were $11.4 \mathrm{~mm}$ and $13.8 \mathrm{~mm}$ respectively. Storms with $P_{i}<I_{f}$ were also well simulated, in all cases giving zero runoff.

The $2^{\text {nd }}$ group of storms that were well simulated were characterised by $P_{i}>I_{f}$ for a certain period during the middle of the storm's duration ( $2^{\text {nd }}, 3^{\text {rd }}$ or $4^{\text {th }}$ quartiles $)$. It can be assumed that the sorptivity and $S D_{m}$ demand for these storms was satisfied by the rain that fell before the intense part started, or else by bursts of intense rains $\left(P_{i}>I_{f}\right)$ that occurred before or after the major intense period (m.i.p.). Huff (1967) defined 'burst' as a cessation in rainfall or an abrupt, persistent change in rainfall rate. But here 'burst of intense rain' was taken as part of the storm that showed $P_{i}$ $>I_{f}$ for a short time interval compared to the m.i.p. of $P_{i}>$ $I_{f}$ At Melkassa this kind of storm was rare. Figure 5 shows one of these storms (DoY 277) during 2004. In this storm the starting point and end-point of the m.i.p. are indicated by the arrowed lines giving $14 \mathrm{~mm}$ and $6 \mathrm{~mm}$ of rainfall on the cumulative rainfall y-axis. Thus, by subtraction, $14 \mathrm{~mm}$ minus $6 \mathrm{~mm}$, gives $8 \mathrm{~mm}$ of expected runoff, the same as the measured value. The model simulated $8.2 \mathrm{~mm}$. Similarly, for storm on DoY 249 of 2003 (Fig. 6) the arrowed lines indicate
$26 \mathrm{~mm}$ and $7 \mathrm{~mm}$ of the cumulative rainfall as boundary values of the m.i.p. This gives $19 \mathrm{~mm}$ of expected runoff on NT plots, while the model simulated $18.2 \mathrm{~mm}$.

It is clear that a long dry period between storms will increase the sorptivity of the soil. In addition, high $S D_{m}$ values were encountered when storms occurred immediately after cultivation on CT plots.. Both these factors will influence the accuracy of simulations. Unlike the Dera Calcic Fluvic Regosol ecotope (Welderufael, 2006), the CT plots on the Melkassa Hypo Calcic Regosol ecotope retained an almost similar $S D$ value $(6 \mathrm{~mm})$ throughout the 2004 rainy season. This may be due to the smaller number of intense rain events after the $2^{\text {nd }}$ cultivation practice carried out on DoY 215.

\begin{tabular}{|l|c|c|}
\hline \multicolumn{3}{|c|}{ TABLE 4 } \\
\begin{tabular}{|} 
Validation of MC model using the $s$ values selected \\
during calibration phase (see Table 3)
\end{tabular} \\
\hline $\begin{array}{l}\text { Objective functions } \\
\text { and indices }\end{array}$ & NT plots & CT plots \\
\hline RMSE & 1.91 & 2.52 \\
\hline RMSEu & 1.89 & 2.33 \\
\hline RMSEs & 0.28 & 0.96 \\
\hline MAE & 1.47 & 2.17 \\
\hline R & 0.99 & 0.96 \\
\hline D-index & 0.99 & 0.90 \\
\hline Slope (b) & 1.10 & 1.70 \\
\hline Intercept (a) & -1.50 & -6.70 \\
\hline RMSEu:RMSE & 0.99 & 0.93 \\
\hline
\end{tabular}


Figure 3

Storm on DoY 199

of 2003 on the

Melkassa Hypo

Calcic Regosol

ecotope
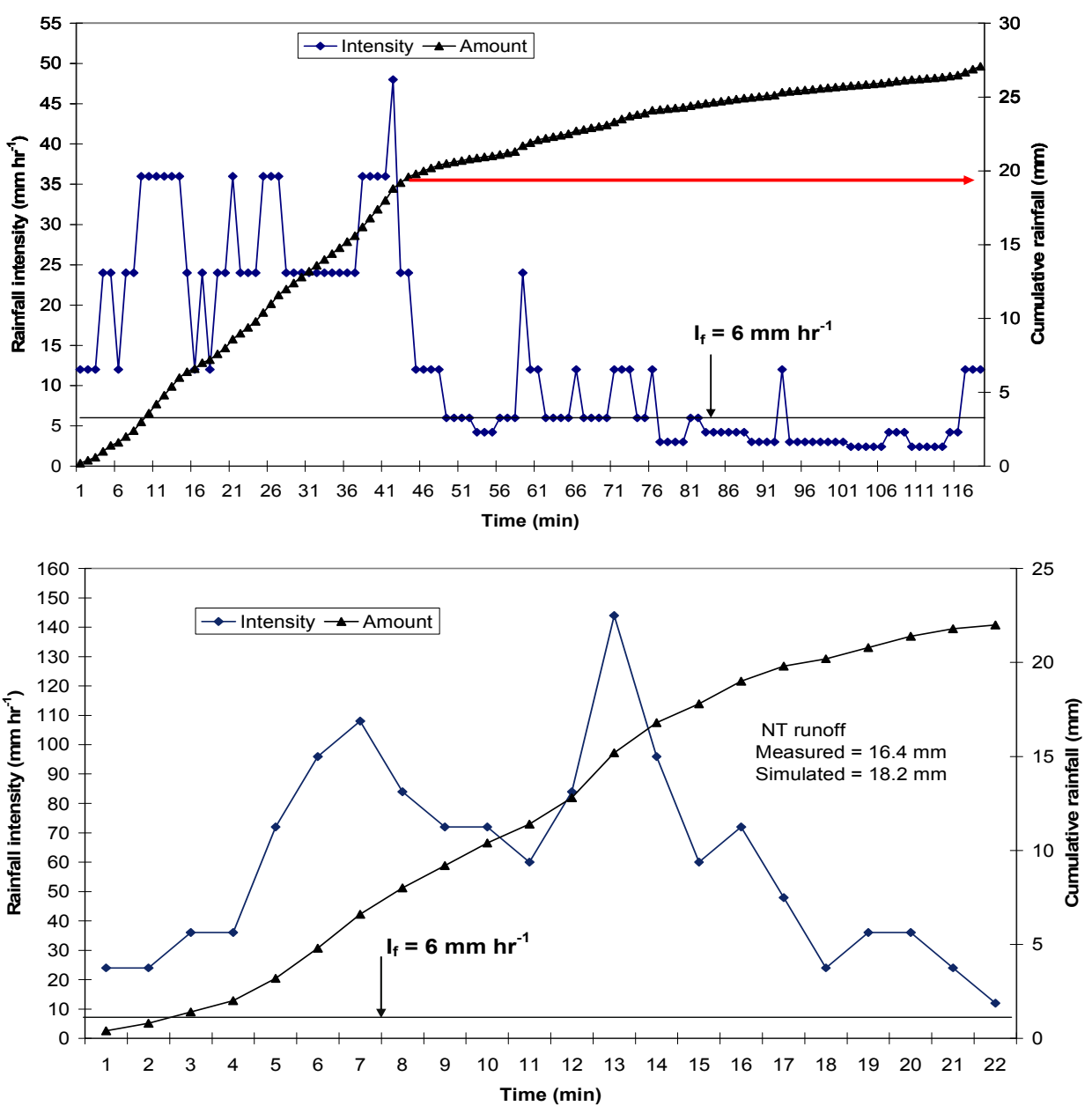

torm on DoY 252

of 2004 on the

Melkassa Hypo

Calcic Regosol

ecotope

Figure 5

Storm on DoY 277

of 2004 on the

Melkassa Hypo

Calcic Regosol ecotope

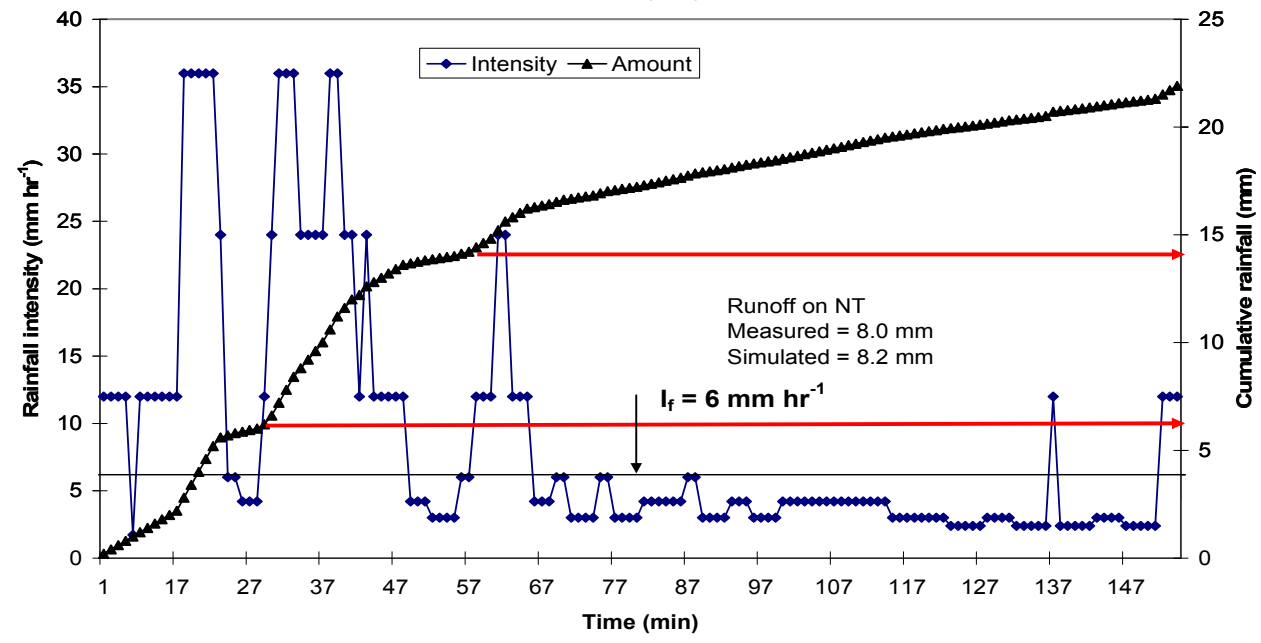

\section{Examples of storms not well simulated}

Storm on DoY 223 of 2004 gave an exceptionally high measured runoff value on the NT plot of $25.9 \mathrm{~mm}$ whereas the simulated value was only $12.2 \mathrm{~mm}$ (Fig. 7). The high measured $R$ was probably due to the fact that it occurred $48 \mathrm{~h}$ after 2 continuous storms on DoY 220 and 221. Although these storms produced little $R(1.8 \mathrm{~mm}$ and $2.3 \mathrm{~mm}$ from NT) they probably contributed enough water to leave the soil surface wet after $48 \mathrm{~h}$. As a result the demand for sorptivity was minimised (an indication of how the model could be improved). The other relevant factor was the occurrence of continuous small bursts of $P_{i}>I_{f}$ that lasted for about $133 \mathrm{~min}$, between $49 \mathrm{~min}$ and
$182 \mathrm{~min}$ (Fig. 7). They covered approximately 3 quarters of the storm's duration. These bursts may not have been considered by the model as significant enough time segments to produce runoff. Similarly, storms on DoY 232 and 251 of 2004 and 2003 , respectively, were under-simulated by the model.

\section{Estimating yield increases using IRWH}

Empirical procedures were followed to estimate the benefit of IRWH to maize production on the Melkassa Hypo Calcic Regosol ecotope. Maize yields and climate data from the Melkassa Agricultural Research Center (MARC) for 16 growing seasons (1988 to 2003) were used. The average maize yield 


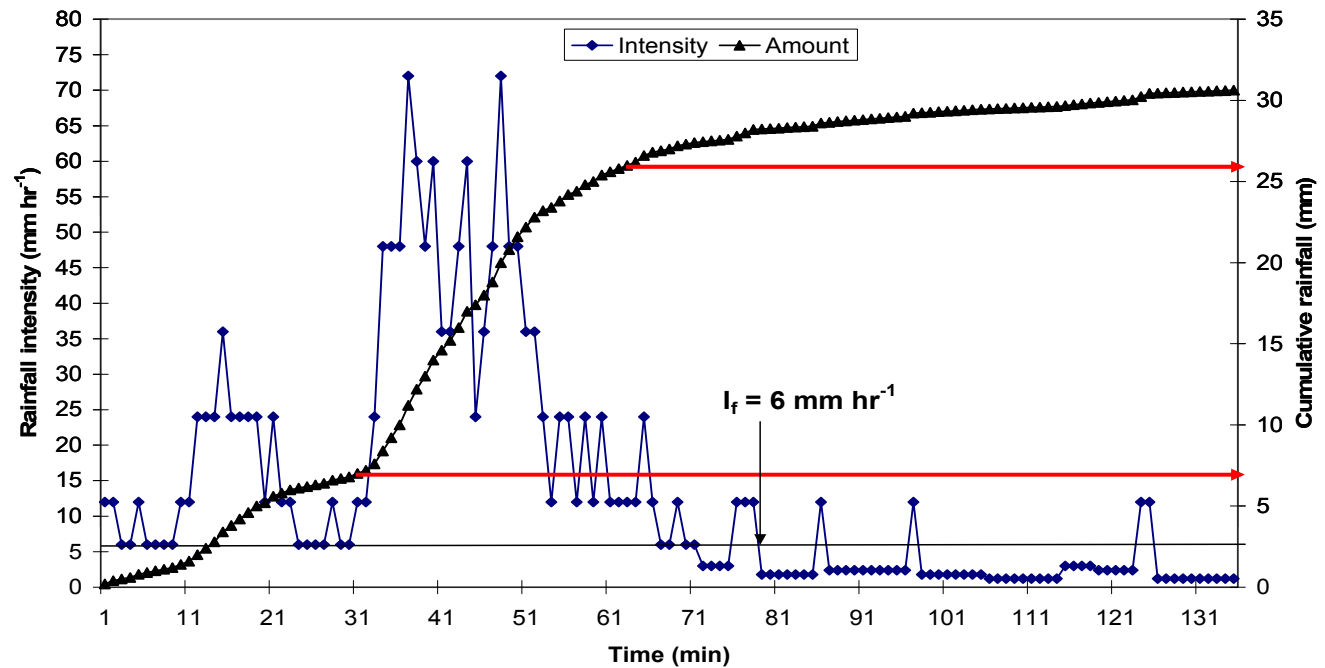

Figure 6

Storm on DoY 249

of 2003 on the

Melkassa Hypo

Calcic Regosol

ecotope

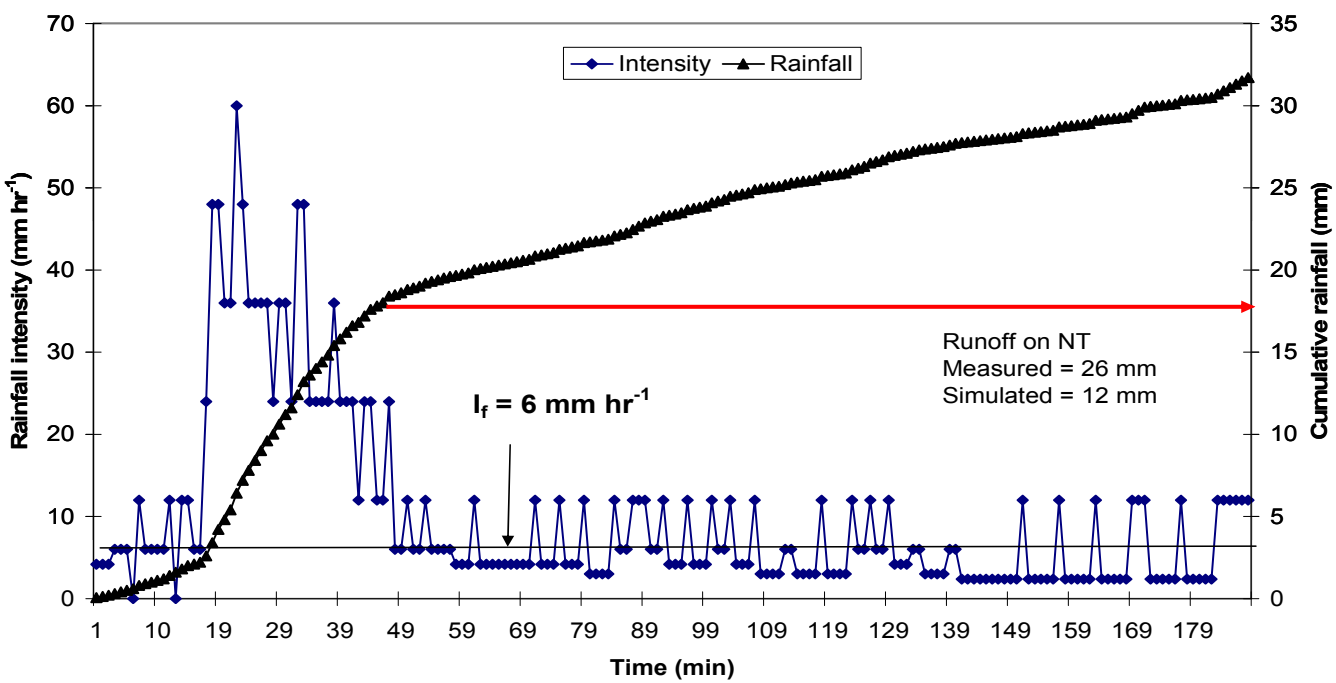

Figure 7

Storm on DoY 223 of 2004 on the Melkassa Hypo Calcic

Regosol ecotope

for this period using conventional tillage was found to be 2115 $\mathrm{kg} \cdot \mathrm{ha}^{-1}$ (Table 5). The climate data included rainfall $(P)$, temperature $(T)$, relative humidity $(R H)$, sunshine hours $(S H)$ and wind speed $(W S)$.

The CROPWAT programme developed by FAO was used for making $E s+T$ estimates. $(E s+T)$ is termed $E T$ in the programme. The detailed description of this programme and the calculations used are given in Welderufael, 2006. The programme first makes use of the climatic data needed (i.e. $P, T, R H, S H$, and $W S$ ) to calculate ETo for each day of each growing season using the Penman-Monteith equation. In the $2^{\text {nd }}$ step the programme combines a crop coefficient $(K c)$ with ETo to estimate the potential $E T$ of maize $\left(K c^{*} E T o\right.$ ) for each growth stage, i.e. the amount of water it would require for $E T$ to attain maximum yield. For each of the 16 growing seasons the ratio of the final grain yield to the sum of the $E T$ values for the season yielded the water productivity $\left(W P_{E T}\right)$ for that particular season (Table 5). The mean $W P_{E T}$ value over all the seasons was found to be $6.5 \mathrm{~kg} \cdot \mathrm{ha}^{-1} \cdot \mathrm{mm}^{-1}$ (Table 5).

To proceed further it is necessary to have an estimate of the fraction of the extra water produced by runoff on the NT plots that will become used for increasing yield, i.e. in this case used specifically for ET. The results obtained by Hensley et al. (2000) and Botha (2007) for field experiments comparing the IRWH and CT production techniques with maize on the Glen/Bonheim ecotope, over 7 growing seasons, was employed as follows to estimate this fraction. The following information was extracted for each growing season:

- Infield runoff $\left(R_{i n f}\right)$ from the IRWH treatment with a bare runoff area

- The difference in water used for ET on IRWH compared to $\mathrm{CT}\left(E T_{\text {IRWH }}-E T_{C T}=\Delta E T\right)$

- The ratio of $\triangle E T / R_{i n f}$

The average value of $\triangle E T / R_{i n f}$ over the 7 seasons was 0.62 . This indicates that on average, on the Glen Bonheim ecotope with maize, $E T_{\text {IRWH }}$ can be expected to be increased to the extent of $0.62 \times R_{\text {if }}$ above the $E T$ of maize with conventional tillage, i.e. $\triangle E T \approx 0.62 * R_{i f}$ A comparison of the runoff characteristics of the Melkassa ecotope and the Glen/Bonheim ecotope shows that they have similar characteristics. Their $I_{f}$ values are also the same $\left(6 \mathrm{~mm} \cdot \mathrm{h}^{-1}\right)$. It is therefore a reasonable $1^{\text {st }}$ approximation to employ the calculated ET: $R_{i f}$ relationship for the Glen/ Bonheim ecotope on the Melkassa Hypo Calcic Regosol ecotope.

The following is the description of the procedure used to estimate the expected maize yield increment with IRWH. Results are presented in Table 5. The rainfall-runoff measurements made on the Melkassa Hypo Calcic Regosol ecotope during 2003 and 2004 are described in Welderufael (2006). From the measurements an empirical/regression equation relating 


\begin{tabular}{|c|c|c|c|c|c|c|}
\hline \multicolumn{7}{|c|}{$\begin{array}{c}\text { TABLE } 5 \\
\text { Maize grain yields and estimates of parameters needed to predict yield increases using IRWH }\end{array}$} \\
\hline Year & $\begin{array}{c}\text { Grain yield } \\
\left(\mathrm{kg}^{\prime} \mathrm{ha}^{-1}\right)\end{array}$ & $\begin{array}{c}R_{\text {if }}^{* 1} \\
(\mathbf{m m})\end{array}$ & $\begin{array}{c}E T_{\text {inc }}^{* 2}{ }^{* 2} \\
R_{\text {if }}^{* 1} \\
* 0.62(\mathrm{~mm}) \\
\end{array}$ & $\begin{array}{c}W P_{E T}^{* 3} \\
\left(\mathbf{k g} \cdot \mathrm{ha}^{-1} \cdot \mathrm{mm}^{-1}\right)\end{array}$ & $\begin{array}{c}W P_{\mathrm{ET}^{*}}{ }_{(\mathrm{kg})} \mathrm{ET} \mathrm{T}_{\mathrm{inc}} \\
\end{array}$ & $\begin{array}{c}\text { Yield increase } \\
(\%)\end{array}$ \\
\hline 1988 & 2707 & 93.6 & 58.0 & 7.5 & 435 & 16.1 \\
\hline 1989 & 2957 & 128.2 & 79.5 & 8.6 & 684 & 23.1 \\
\hline 1990 & 3800 & 190.0 & 117.8 & 12.2 & 1437 & 37.8 \\
\hline 1991 & 1444 & 138.7 & 86.0 & 5.1 & 439 & 30.4 \\
\hline 1992 & 1190 & 172.2 & 106.8 & 3.2 & 342 & 28.7 \\
\hline 1993 & 2479 & 129.6 & 80.3 & 8.7 & 699 & 28.2 \\
\hline 1994 & 1388 & 157.9 & 97.9 & 4.8 & 470 & 33.9 \\
\hline 1995 & 2396 & 266.7 & 165.4 & 7.1 & 1174 & 49.0 \\
\hline 1996 & 2709 & 194.0 & 120.3 & 7.8 & 938 & 34.6 \\
\hline 1997 & 2187 & 242.8 & 150.5 & 7.1 & 1069 & 48.9 \\
\hline 1998 & 1460 & 266.7 & 165.4 & 4.3 & 711 & 48.7 \\
\hline 1999 & 2346 & 194.0 & 120.3 & 7.3 & 878 & 37.4 \\
\hline 2000 & 2346 & 180.1 & 111.7 & 7.2 & 804 & 34.3 \\
\hline 2001 & 1876 & 175.2 & 108.6 & 5.9 & 641 & 34.2 \\
\hline 2002 & 262 & 47.5 & 29.4 & 1.2 & 35 & 13.4 \\
\hline 2003 & 2300 & 162.8 & 101.0 & 6.2 & 626 & 27.2 \\
\hline Means & 2115 & & & 6.5 & 711 & 32.9 \\
\hline
\end{tabular}

*1 $\quad R_{\text {if }}=$ estimate of infield runoff based on measurements made on this ecotope during 2003 and 2004

(Welderufael, 2006).

*2 $E T_{\text {inc }}=$ estimate of the increase in ET due to $R_{\text {if }}$

*3 $\quad W P_{E T}=$ water productivity calculated based on evapotranspiration (ET)

NT plot runoff to rainfall events $>9 \mathrm{~mm}$ was developed. The equation is:

$$
R=0.714 P-6.8959\left(R^{2}=0.87\right)
$$

where:

$R$ is the estimated runoff in $\mathrm{mm}$

$P$ is the amount of rain $(>9 \mathrm{~mm})$ of the rainfall event (Welderufael, 2006)

Applying this equation to each rainfall event during each growing season from 1988 to 2003 (Table 5) provides an estimate of what the runoff $\left(R_{i f}\right)$ would have been from the runoff strip (Fig. 1) had IRWH been employed. Multiplication of this value by 0.62 gives an estimate of the expected $E T$ increment $\left(E T_{i n c}\right)$. The multiplication of $E T_{\text {inc }} * W P_{E T}$ provides a logical estimate of the increased yield with IRWH.

Results are presented in Table 5. Values vary between $13 \%$ and $49 \%$. The mean increase is shown to be $33 \%$, which represents an estimated average annual yield increase of $711 \mathrm{~kg} \cdot \mathrm{ha}^{-1}$.

\section{Conclusions}

The 3 objectives of the study were achieved. Firstly, the Morin and Cluff runoff model was successfully calibrated and validated. Appropriate values for the 3 parameters needed by the model for use on the Melkassa Hypo Calcic Regosol were determined, i.e. $I_{f}=6 \mathrm{~mm} \cdot \mathrm{h}^{-1} ; s$ for NT and CT were $1 \mathrm{~mm}$ and $6 \mathrm{~mm}$ respectively; and $\gamma=0.6 \mathrm{~mm}^{-1}$. Secondly, rainfallrunoff relationships on the Melkassa ecotope during 2004 were quantified giving values of 0.59 and 0.40 for the NT and CT treatments, respectively. The significant difference between the runoff on the 2 treatments during 2004 was caused mainly by the 2 cultivation operations on the CT plots that caused large $S D m$ and had a major influence on runoff. Thirdly, maize yield benefits using the IRWH technique instead of conventional tillage on this ecotope were estimated to be between 35 and $1437 \mathrm{~kg} \cdot \mathrm{ha}^{-1}$.

The study shows how crop yields in semi-arid regions of Sub-Saharan Africa could be increased significantly by employing in-field rainwater harvesting rather than conventional tillage. Since it is expected that the technique will only be successful on ecotopes with specific properties, prior detailed characterisation of these relevant properties is recommended.

\section{References}

BENNIE ATP and HENSLEY M (2001) Maximizing precipitation utilization in dry land agriculture in South Africa. J. Hydrol. 241 125-139.

BENNIE ATP, HOFFMAN JE, COETZEE MJ and VREY HS (1994) Storage and Use of Rain Water in Soil for the Stabilization of Plant Production in Semi-Arid Areas [Afr]. WRC Report No. 227/1/94. Water Research Commission, Pretoria, South Africa.

BERRY WAJ and MALLETT JB (1988) The effect of tillage: Maize residue interactions upon soil water storage. S. Afr. J. Plant Soil 5 57-64.

BOTHA JJ (2007) Evaluating Maize and Sunflower Production in a Semi-Arid Area Using Infield Rainwater Harvesting. Ph. D. Thesis. University of the Free State, Bloemfontein, South Africa.

BOTHA JJ, VAN RENSBURG LD, ANDERSON JJ, HENSLEY M, MACHELI MS, VAN STADEN PP, KUNDHLANDE G, GROENEWALD DG and BAIPHETHI MN (2003) Water Conservation Techniques on Small Plots in Semi-Arid Areas to Enhance Rainfall Use Efficiency, Food Security, and Sustainable Crop Production. WRC Report No. 1176/1/03. Water Research Commission, Pretoria, South Africa. 
DU PLESSIS MC and MOSTERT JWC (1965) Runoff and soil losses at the Agricultural Research Centre, Glen. S. Afr. J. Agric. Sci. 8 1051-1061.

FAO (1984) Provisional Soil Association Map of Ethiopia (1:2 000000$)$ based on the work of H.Y. Wijntje-Bruggeman AG:DP/ETH/82/010 Field Document 6, Addis Ababa, Ethiopia.

FAO (1998a) Soils of East Africa. www.67.95.153.93/RiftValley_soils. php (Accessed on 5 May 2005).

FAO (1998b) World Reference Base for Soil Resources. World Soil Resource Reports 84. FAO, Rome.

GIBBS MD, RUSSEL WB and KLOPPERS PP (1993) Erosion studies using natural runoff plots. Annual Report on Research Facet No. N5711/38/1/1 to the Department of Agriculture, Pretoria, Republic of South Africa.

GICHERU PT, GACHENE CKK and BIAMAH EK (1998) Effects of tillage and mulching on soil moisture conservation and crop production. Appl. Plant Sci. 12 5-9.

GRAEF F and STAHR K (2000) Incidence of soil surface crust types in semi-arid Niger. Soil Tillage Res. 55 213-218.

HAYLETT DG (1960) Runoff and soil erosion studies at Pretoria. S. Afr. J. Agric. Sci. 3 379-394.

HENSLEY M, BOTHA JJ, ANDERSON JJ, VAN STADEN PP and DU TOIT A (2000) Optimizing Rainfall Use Efficiency for Developing Farmers with Limited Access to Irrigation Water. WRC Report No. 878/1/00. Water Research Commission, Pretoria, South Africa.

HUFF FA (1967) Time distribution of rainfall in heavy storms. Water Resour. Res. 3 1007-1019.

ITANNA F (2005) Sulphur distribution in five Ethiopian Rift Valley soils under humid and semi-arid climate. J. Arid Environ. 62 597-612.

KRONEN M (1994) Water harvesting and conservation techniques for smallholder crop production system. Soil Tillage Res. 32 71-86.

MADSEN H, WILSON G and AMMENTORP HC (2002) Comparison of different automated strategies for calibration of rainfall-runoff models. J. Hydrol. 261 Issue (1-4) 48-59.
MINISTRY OF AGRICULTURE (MoA) (2000) Agro-Ecological Zones of Ethiopia, Natural Resource Management and Regulatory Department, Addis Ababa, Ethiopia.

MORIN J and BENYAMINI Y (1977) Rainfall infiltration into bare soils. Water Resour. Res. 3 813-817.

MORIN J and CLUFF CB (1980) Runoff calculation on semi-arid watersheds using a Rotadisk Rainulater. Water Resour. Res. 16 1085-1093.

MORIN J, RAWITZ E, HOOGMOED WB and BENYAMINI Y (1983) Tillage practice for soil and water conservation in the Semi-Arid Zone III: Runoff modelling as a tool for conservation tillage design. Soil Tillage Res. 4 215-224.

MWAKALILA SS and HATIBU N (1993) Rain water harvesting for crop production in Tanzania. Proc. $3^{\text {rd }}$ Annual Scientific Conference of the SADC-L\& WMRP. October 1992, Harare, Zimbabwe. 513-525.

OJASVI PR, GOYAL RK and GUPTA JP (1999) The micro-catchment water harvesting technique for the plantation of jujube (Zizyphus mauritiana) in an agroforestry system under arid conditions. Agric. Water Manage. 41 95-105.

OWEIS T, HACHUM A and KIJNE J (1999) Water harvesting and supplementary irrigation for improved water use efficiency in dry areas. IWMI Contribution (No. 7) to System-Wide Initiative on Water Management (SWIM), Colombo, Sri Lanka.

SOIL CLASSIFICATION WORKING GROUP (1991) Soil Classification - a Taxonomy System for South Africa. Mem. Agric. Nat. Resource No. 15. Department of Agricultural Development, Pretoria, South Africa.

WELDERUFAEL WA (2006) Quantifying Rainfall-Runoff Relationships on Selected Benchmark Ecotopes in Ethiopia: A Primary Step in Water Harvesting Research. Ph.D. Thesis, University of the Free State, Bloemfontein, South Africa.

WILLMOTT CJ (1981) On the validation of models. Phys. Geogr. 2 184-194.

ZERE TB, VAN HUYSSTEEN CW and HENSLEY M (2005) Estimation of runoff at Glen in the Free State Province of South Africa. Water SA 31 (1) 17-21. 